\title{
LINE WEBTOON SEBAGAI INDUSTRI KOMIK DIGITAL
}

\author{
Annisa Fitriana Lestari, Irwansyah
}

Universitas Indonesia

\begin{abstract}
Because of internet and smartphones, various industries and their products have changed. Comics as one form of the reading industry also experienced this impact. Conventional comics are changing into digital comics, which can be read via cellphones. One of the digital comic services is LINE Webtoon, which has successfully become a popular comic application in various countries, including Indonesia. The purpose of this study is to provide an overview, deepen and develop the concept of Webtoon, especially LINE Webtoon. This research using qualitative descriptive as method. The results showed that the Webtoon was developed from a conventional form of comics in South Korea called manhwa. Manhwa change into digital because the decline of conventional comic market and technological advancements that developed in South Korea. As an industry, LINE Webtoon expanded its business with presenting paid content, creating advertisements, looking for talented comics, and adapting across media to popular Webtoon works.
\end{abstract}

Keywords

Digital Comics, Industry, Webtoon

Correspondence Contact

afelonew@gmail.com

\section{PENDAHULUAN}

Kehadiran internet dan smartphone telah mengubah gaya, aktivitas dan kebiasaan manusia. Internet adalah teknologi yang memberikan kemampuan penyiaran yang dilakukan sekali dan tersebar di seluruh dunia, suatu mekanisme penyebaran informasi, dan media yang berkolaborasi serta wadah interaksi individu dengan komputer tanpa mengalami gangguan lokasi geografis (Leiner, 1997). Memasuki tahun 2000-an, internet berkembang pesat di Indonesia. Asosiasi Penyelenggara Jasa Internet Indonesia (APJII) menunjukkan hasil surveinya pada tahun 2017 mengenai penetrasi pengguna internet, dimana jumlah presentasinya sebesar 54,68 persen atau 143,26 juta jiwa dari total populasi penduduk Indonesia (Lestari, 2018). Smartphone adalah ponsel yang memiliki kemampuan komputer dan internet sebagai alat pencarian, yang membedakan adalah ukuran dan mobilitasnya (Anh, 2016). Data yang ditampilkan Hootsuite pada tahun 2018 menunjukkan bahwa pengguna ponsel di Indonesia telah mencapai 67 persen atau 177,9 juta jiwa (Sidik, 2018). Hal ini dapat menunjukkan bahwa sebagian besar masyarakat Indonesia mulai mengaplikasikan kegiatan digital dalam setiap kebiasaanya, salah satunya adalah membaca.

Peter, Weber, dan Roeber (1987, dalam Gilakjani dan Sabouri, 2016) menjelaskan bahwa membaca adalah proses dalam penciptaan makna dengan melibatkan pengetahuan pembacanya, informasi dari teks, dan konteks bacaanya. Industri membaca berkembang pesat sejak penemuan mesin cetak oleh Gutenberg pada tahun 1455 (Kilgour, 1998). Melalui penemuan Gutenberg dengan alat yang dikenal dengan moving type, proses percetakkan buku atau Bible pada saat itu sangatlah pesat dan cepat (Turow, 2009). Meski belum sepenuhnya berubah, kehadiran internet dan smartphone dalam industri baca memudahkan individu 
untuk mengakses bahan bacaan dari berbagai sumber diseluruh dunia, mengurangi biaya dalam membeli bacaan bentuk cetak, dan merubah karakter membaca menjadi lebih cepat atau disebut dengan skimming (Malviya, 2010). Dalam era ini dikenal istilah baru yaitu digital reading. Digital reading adalah yaitu proses membaca yang melibatkan kemampuan untuk bernavigasi ke halaman hypertexts; memahami dan menyatukan berbagai sumber informasi; serta evaluasi dari sebuah informasi (Afflerbach dan Cho, 2010).

Salah satu bentuk revolusi industri baca dan penerapan digital reading telah terjadi pada komik. Komik adalah gambar yang saling berdekatan dengan gambar lainnya yang sengaja diurutkan untuk menyampaikan informasi dan menghasilkan respon estetika dari pembacanya (Cohn, 2005). Industri baca yang berubah mendorong perubahan komik untuk mengikuti gaya yang baru sesuai dengan teknologi komunikasi yang ada. Hal ini juga memunculkan istilah baru yang dikenal dengan komik digital atau digital comic. Komik digital adalah komik yang dipublikasikan secara digital; terdiri dari gambar yang tunggal atau tersusun dari beberapa bagian; memiliki jalur membaca yang selaras; memiliki bingkai yang terlihat; terdapat simbol seperti balon kata; dan terdapat gaya tulisan yang mengkomunikasikan makna visualnya (Aggleton, 2018). Memanfaatkan internet dan smartphone, komik digital hadir dalam bentuk aplikasi seluler atau mobile application. Aplikasi seluler atau mobile application adalah sebuah perangkat lunak yang diciptakan untuk memenuhi suatu tujuan dengan diunduh pengguna ke perangkat selulernya (Albert, dkk., 2017).

Terdapat banyak bentuk komik digital dalam bentuk aplikasi, salah satunya adalah LINE Webtoon. LINE Webtoon adalah salah satu platform komik digital dari Korea Selatan yang diluncurkan oleh salah satu perusahaan teknologi yaitu LINE Corporation dengan NAVER Corporation (Fatimah, 2018). Tahun 2017, LINE Webtoon secara global mendapatkan pendapatan sebesar 7,07 juta dolar Amerika (Bhaskara, 2019). Memasuki tahun 2019, pasar LINE Webtoon diperkirakan akan naik menjadi 8,4 juta dolar Amerika. Dari data tersebut menunjukkan bahwa secara pasar global, LINE Webtoon akan meningkat tajam dibandingkan komik bentuk cetak yang terus menurun.

LINE Webtoon menjadi aplikasi komik digital dengan memiliki 6 juta pengguna aktif di Indonesia dan 35 juta pengguna aktif di seluruh dunia (Agnes, 2016). LINE Webtoon memiliki banyak penggemar di seluruh dunia, 75\% pembacanya berada di kisaran usia 20 tahun atau diatasnya (AFP, 2015). Popularitas LINE Webtoon ini menimbulkan pengembang bisnis dari aplikasi komik digital ini. Pertama, LINE Webtoon kini dinikmati tidak hanya masyarakat Indonesia, tetapi negara lain seperti Amerika, Jepang, Thailand, dan lain-lain. Untuk membuat aplikasi komik digital ini menjadi bagian dari produk lokal negara tersebut, LINE Webtoon mengadakan kontes dan edukasi untuk kreator lokal dengan program Webtoon Challenge dan Webtoon Contest (Bhaskara, 2019). Kedua, banyak dari karya kreator LINE Webtoon yang diadaptasikan menjadi drama atau film. Selain dua bentuk dampak popularitasnya, LINE Webtoon juga mengembangkan bisnisnya dengan menerapkan iklan dan kehadiran konten berbayar pada aplikasi versi terbarunya.

Penjabaran yang telah dijelaskan di atas, membuat penulis tertarik untuk meneliti LINE Webtoon sebagai salah satu bentuk dari perkembangan teknologi komik digital yang menjadi sebuah industri yang memiliki minat pasar yang tinggi. Tujuan dari penelitian ini adalah untuk meningkatkan kejelasan tentang konsep, memberikan gambaran secara holistik dari konsep yang dibangun dari penelitian-penelitian terdahulu, dan menjabarkan perkembangan baru dari konsep LINE Webtoon sebagai industri dari komik digital. Manfaat penelitian ini adalah untuk memberikan pendalaman dari konsep; menambahkan referensi dalam penelitian terkait; memberikan gambaran secara holistik dari konsep LINE Webtoon sebagai 
perkembangan teknologi komik yang telah berubah menjadi produk digital dan membentuk sebuah industri

\section{KAJIAN TEORITIK}

\section{Perkembangan Webtoon}

Istilah komik didapatkan dari lukisan-lukisan yang berada di gua Cro-Magnon hingga hieroglif Mesir Kuno (Tychinski, 2004 dalam Lim, 2012). Lukisan-lukisan Mesir Kuno (3.500 SM) menjadi dasar bentuk komik saat ini yang terbagi menjadi dua jenis format, yaitu timur (realistis) dan barat (karikatur) (In-Ha, 2005 dalam Lim, 2012).

Komik modern diperkenalkan oleh Rodolphe Topffer (McCloud, 1993 dalam Lim, 2012). Karya Topffer merupakan cerita bergambar sindiran ringan dengan kata-kata dan batas panel yang dimulai pada pertengahan tahun 1800-an di Eropa. Memasuki abad ke-19, bentuk komik ini dimusnahkan dan disempurnakan kembali dalam majalah humor mingguan dan bulanan di Inggris (Harvey, 2009 dalam Lim, 2012). Komik juga populer di negara-negara di Asia Timur, seperti Korea Selatan (Kim, 2006 dalam Lim, 2012).

Manhwa adalah sebutan bagi semua genre komik Korea baik cetak maupun online (Jang dan Song, 2017). Manhwa terbagi menjadi 23 genre, seperti fiksi ilmiah (SF), horor, dan drama. (Korea Manhwa Archive dalam Lim, 2012). Manhwa mulai diperkenalkan setelah tahun 1965 ketika Korea Selatan memutuskan untuk kembali membangun hubungan dengan Jepang (Koh, 2012). Namun mulai akhir tahun 1990, banyak buku komik yang dipindai dan dijadikan bentuk digital secara illegal dengan sudah bekembangnya teknologi infomasi pada saat itu (Lee, Choi, dan Kim, 2015). Penerbitan ilegal dan krisis ekonomi pada tahun 1997 hingga 1998 memberi dampak melemahnya industri komik cetak (Lee, Choi, dan Kim, 2015).

Korea Selatan menjadi negara terdepan dalam pengembangan internet dan teknologi komunikasi, sehingga banyak pelopor pengembangan bentuk baru dari manhwa menjadi dalam bentuk digital yang dapat dinikmati secara gratis tetapi tidak melanggar hukum, yang dikenal dengan Webtoon. Webtoon disebut sebagai web manhwa karena didukung oleh teknologi digital dan menggunakan jaringan dari situs web dan ponsel (Jin, 2015 dalam Jang dan Song, 2017).

Webtoon pada generasi pertama memanfaatkan teknologi gambar dan animasi Flash (Norin, 2018). Teknologi ini memungkinkan bagi Webtoon untuk dapat dibaca dengan membalik, memperbesar, dan memperkecil tampilan halaman secara otomatis.

Generasi kedua Webtoon hadir dengan format yang sama seperti sekarang ini dimana memanfaatkan kemajuan teknologi Liquid Crystal Display (LCD) (Norin, 2018). Teknologi ini merubah cara baca Webtoon menjadi vertikal dari atas ke bawah, serta kulitas gambar sangat berpengaruh dimana membutuhkan pixel yang tinggi.

Pada Webtoon generasi ketiga sebenarnya tidak ada perubahan yang signifikan terjadi, hanya banyak pembuat Webtoon yang menyesuaikan dengan perubahan ponsel mobile atau tablet (Norin, 2018).

\section{Profil LINE Webtoon}

LINE Webtoon atau yang lebih dikenal dengan Webtoon adalah sebuah platform komik digital yang dapat diakses tanpa biaya atau gratis (Webtoon.com, 2019). Berbeda dengan komik konvensional, LINE Webtoon menghadirkan konten digital yang hadir secara kontinu dan 
baru setiap minggunya. Komik digital ini dapat diakses melalui web atau mobile baik memiliki sistem iOS atau Android.

LINE Webtoon didirikan oleh Kim Junkoo pada tahun 2004 di Korea Selatan (Acuna, 2016). Junkoo melihat bahwa pada akhir tahun 1990 hingga awal tahun 2000-an, penerbitan komik di Korea Selatan mulai padam karena adanya penurunan ekonomi dan pemerintah menganggap komik memberikan pengaruh berbahaya pada saat itu. Untuk merubah pemikiran tersebut, Junkoo mencetuskan LINE Webtoon sebagai baru bagi pembaca komik, dengan akses yang mudah dan gratis, serta ide yang asli.

Pada awal peluncurannya, nama LINE Webtoon adalah NAVER Webtoon yang disesuiakan dengan nama perusahaan awal publikasi aplikasi ini, yaitu Naver Corporation (Webtoon.com, 2019). Naver Corporation adalah perusahaan teknologi, informasi dan komunikasi terbesar di Korea Selatan, dengan menghadirkan produk seperti mesin pencarian, aplikasi pengiriman pesan, video, dan komik digital (www.navercorp.com, 2019). Tahun 2014, untuk menyasar pasar secara global NAVER Webtoon bekerja sama dengan LINE Corporation (Bhaskara, 2019). LINE Corporation adalah perusahaan teknologi yang berbasis di Jepang dan mengembangkan usaha di Korea Selatan dengan nama LINE Plus Corporation (Linecorp.com, 2019). Melalui kerjasama ini, LINE Webtoon berhasil diluncurkan di berbagai negara, salah satunya Indonesia.

LINE Webtoon membagi jenis-jenis komiknya berdasarkan genre dan usia (www.webtoons.com, 2019). Dalam genre terdapat tiga belas kelompok komik, yaitu drama, fantasy, comedy, action, slice of life, romance, superhero, heartwarming, historical, thriller, sports, sci-fi, horror, dan informative. Sementara berdasarkan usia, LINE Webtoon Indonesia dibagi menjadi tiga kelompok, yaitu remaja, 20-an, dan 30-an.

Terdapat bentuk berbeda antara LINE Webtoon dengan komik secara konvensional. Perbedaan ini terlihat dari karakteristik dan elemen-elemen yang dimiliki LINE Webtoon (Jang and Song, 2017), yaitu:

1. Vertical scrolling and presenting sequence

Cara membacanya LINE Webtoon berbeda dengan membaca komik pada umumnya, yaitu dengan cara membalik halaman secara horizontal dari kanan ke kiri. Memanfaatkan smartphone yang saat ini dominan sudah berbasis layar sentuh, LINE Webtoon dibaca secara vertikal dari atas hingga ke bawah tanpa putus. Fitur ini dianggap mampu membantu pembaca memahami cerita dengan cepat dan memunculkan perasaan seperti menonton film pendek. 


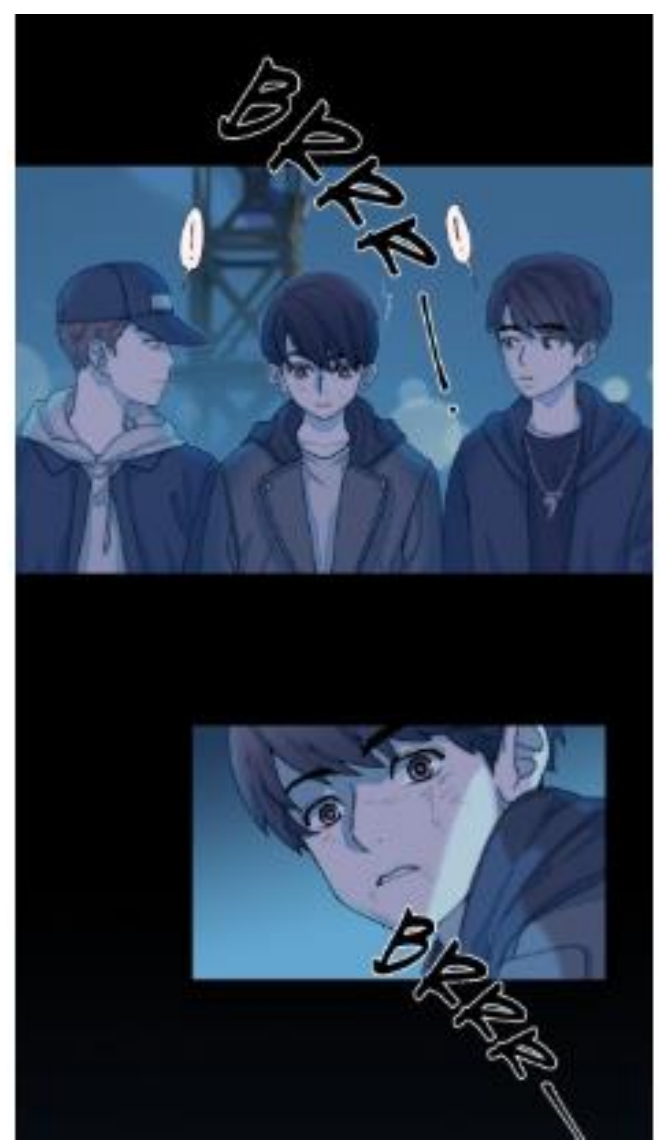

Gambar 1. Bentuk Vertikal Tampilan LINE Webtoon (LICO, 2019)

\section{Nonlinear storytelling}

Pada akhir setiap episode LINE Webtoon yang dipublikasikan, terdapat kolom komentar yang menjadi wadah bagi pembacanya untuk memberikan pendapat melalui pesan teks kepada pembuat LINE Webtoon tersebut. 


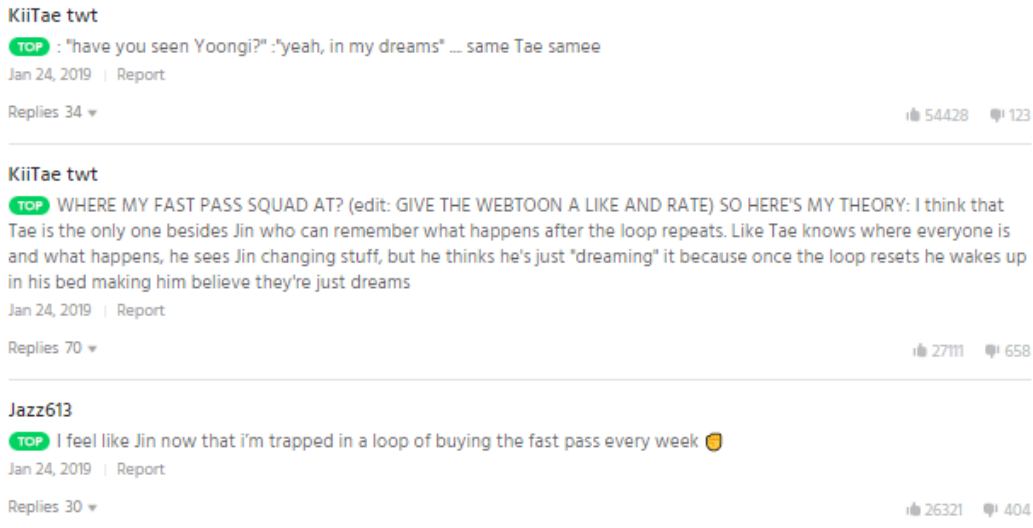

Gambar 2. Bentuk Kolom Komentar Pada LINE Webtoon (LICO, 2019)

3. Sound and interactive motion

Tidak hanya gambar dalam bentuk dua dimensi (2D), LINE Webtoon terus mengembangkan aplikasinya hingga dapat memberikan berbagai efek dalam tampilannya. Saat ini LINE Webtoon menggunakan teknologi FX Toon, yang membuat komik yang dibaca dapat memunuclkan suara dan gambar bergerak di dalamnya.

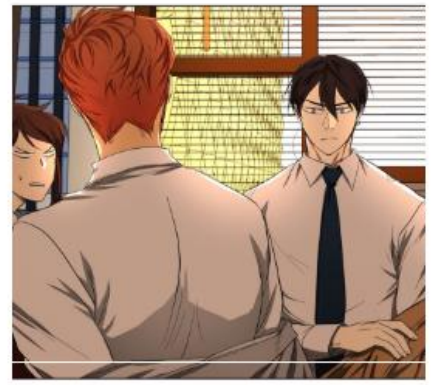

Gambar 3. Bentuk Seri LINE Webtoon yang Disiipkan Musik di Dalamnya (Quimchee, 2018) 


\section{LINE Webtoon di Indonesia}

LINE Webtoon masuk ke Indonesia pada April 2015 (Agnes, 2017). Dari 35 juta pengguna aktif di seluruh dunia, Indonesia menjadi pasar tertinggi LINE Webtoon dengan terdapatnya 6 juta pengguna aktif pada data Agustus 2016 (Agnes, 2016). Tingginya minat pembaca LINE Webtoon ini juga dibarengi dengan tingginya kreator Webtoon atau Webtoonist lokal, dimana hingga tahun 2017 sudah terdapat 65 Webtoonist lokal. Tiga dari 65 Webtoonist Indonesia tersebut, karyanya telah memasuki pasar Thailand dan Taiwan.

Pada LINE Webtoon Indonesia terdapat 131 judul Webtoon dengan berbagai genre dan diantaranya terdapat 58 judul Webtoon dari Webtoonist lokal (Agnes, 2017). Dari ke 58 judul Webtoon lokal tersebut, 15 judul telah selesai dirilis dan 43 sisanya sedang dalam masa perilisan. Dari 58 judul Webtoon lokal tersebut, terdapat 5 judul yang populer dengan dilihat pelanggannya (subscribe) (Agnes, 2017b). Posisi pertama dengan genre romance terdapat 'Eggnoid' karya Archie The Red Cat memiliki 2,3 juta subscribers. Selanjutnya dengan jumlah yang sama namun genre komedi, terdapat karya Nurfadli Mursyid dengan judul 'Tahilalats'. Di posisi ketiga terdapat Webtoon dengan judul 'Alice' karya Angellina dengan genre romance memiliki 1,4 juta subscribers. Kemudian di posisi empat, memiliki jumlah subcribers yang sama dengan 'Alice', terdapat Webtoon karya Annisa Nisfihani dengan judul 'My Pre-Wedding'. Terakhir diposisi kelima terdapat karya milik Senaloli dengan judul 'Wonderwall' dengan 1,2 juta subscribers. Tingginya jumlah subscribers pada kelima Webtoon populer ini dapat menunjukkan minat yang tinggi dari pecinta komik di Indonesia.

\section{Pembaca LINE Webtoon}

Dalam syarat penggunaannya, LINE Webtoon membatasi pembacanya minimal berusia 13 tahun (www.webtoons.com, 2019a). Sementara LINE Webtoon juga menunjukkan Webtoon populer bedasarkan usia yang berbeda sesuai dengan bahasa yang digunakan. Pada LINE Webtoon Indonesia, kelompok usia dibagi menjadi remaja, 20-an, dan 30-an (www.webtoons.com, 2019b). Sementara ketika mengakses LINE Webtoon berbahasa Inggris akan tampil kelompok pembaca berdasarkan jenis kelamin dan usia, yaitu laki-laki dan perempuan; serta kelompok usia belasan (10 tahunan keatas), 20 tahun keatas, dan 30 tahun keatas.

Perwakilan LINE Webtoon menyatakan bahwa setiap harinya dari lebih 6 juta pembaca, platform komik digital ini tetap dapat mempertahankan keseimbangan pembaca antara lakilaki dan perempuan dengan ratio 50:50 (Macdonald, 2016). Menurut JunKoo (Macdonald, 2016) keseimbangan pembaca baik laki-laki maupun perempuan disebabkan karena Webtoonist mampu menciptakan karakter yang kuat dan hadirnya genre yang beragam.

Sementara hasil survei yang dilakukan di Indonesia menunjukkan bahwa pembaca LINE Webtoon lebih banyak berjenis kelamin perempuan dibandingkan laki-laki dengan persentase 46,30\% dan 30,92\% (Rina, 2016). Lebih dari 70\% responden menyatakan alasan memilih LINE Webtoon karena mampu menghadirkan cerita-cerita yang menarik. Meski tersedia dalam berbagai macam bahasa, responden sebagai pembaca LINE Webtoon di Indonesia dengan presentase sebanyak $62,21 \%$ tetap memilih mengakses dalam bahasa Indonesia. Genre yang diminati oleh responden sebagai pembaca LINE Webtoon di Indonesia adalah komedi dengan presentase sebesar $69.77 \%$. Dengan presentase sebesar $37,79 \%$, responden bersedia untuk merekomendasikan LINE Webtoon kepada teman-temannya. Meski bergitu, 78,49\% responden menyatakan LINE Webtoon perlu ditingkatkan kualitasnya, terutama pada gambar, suara, dan hasil terjemahan Webtoon yang berasal dari negara berbeda.

Konten Berbayar di LINE Webtoon 
Membaca Webtoon menjadi suatu hal yang menyenangkan bagi beberapa individu dan setiap minggunya pembaharuan episode sangatlah dinatikan. Kadang kala menunggu pembaharuan dari episode selanjutnya suatu judul Webtoon membuat pembaca tidak sabar. Untuk mengurangi rasa penasaran pembaca akan episode selanjutnya, LINE Webtoon memuat fitur baru yang dikenal dengan Koin. Koin adalah adalah mata uang khusus pada aplikasi LINE Webtoon di Android dan iOS yang digunakan pembaca untuk membeli konten dan memperoleh akses pada episode selanjutnya (help2.line.me, 2019). Fitur koin dapat ditemukan ketika pengguna melalukan pembaharuan pada aplikasi LINE Webtoon dengan versi 2.1.2 (Fitrianindita, 2018). Pembelian koin dapat dilakukan melalui Google Play atupun App Store. Fitur koin ini memiliki keterbatasan, seperti berikut:

1. Apabila melakukan penggantian ponsel dari Android ke iOS maka koin yang ada di akun LINE Webtoon akan hangus karena adanya perbedaan peraturan antara penyedia platform (Google, Apple).

2. Koin yang dibeli hanya dapat digunakan pada konten dengan bahasa tertentu yang diaplikasikan dalam akun LINE Webtoon. Apabila pengguna LINE Webtoon melakukan perubahan bahasa, maka akses pada konten Webtoon yang sudah dibeli akan menghilang.

3. Tidak bekerjanya fitur tangkapan layar (screenshot) pada ponsel pengguna baik Android ataupun iOS.

\section{Iklan di LINE Webtoon}

Periklanan adalah salah satu bentuk komunikasi yang berbayar dengan dimediasi suatu sumber yang dapat diidentifikasi, disusun untuk dapat mmberikan pengaruh penerima pesan untuk mengambil suatu tindakan, baik saat itu juga atau di masa yang akan datang (Richards dan Curran, 2002 dalam (Karimova, 2014). Dengan berkembangnya media baru, berbagai merek atau organisasi atau perusahaan memanfaatkan iklan yang disediakan Webtoon sebagai salah satu cara komunikasi dengan menggunakan berbagai jenis atraksi kepada konsumen (Hee dan Yeob, 2018). Dalam strategi ekspresi, pada Webtoon terdapat dua tipe bentuk iklan (Hee dan Yeob, 2018), yaitu:

1. Real type yaitu bentuk iklan dalam bentuk gambar atau foto yang disisipkan dalam Webtoon.

2. Webtoon type adalah bentuk iklan yang memanfaatkan cerita dan kartun dari Webtoonist yang disisipkan dalam Webtoon.

Bentuk real type pada LINE Webtoon dikenal dengan Ad Display. Ad Display adalah penempatan pesan promosi pada beberapa dan seluruh seri Webtoon yang bertujuan untuk mempublikasikan produk pihak ketiga (organisasi atau perusahaan) (www.webtoons.com, 2018). Iklan yang ditampilkan dapat hadir dalam bentuk teks, grafik, audio, video, dan atau kombinasinya. Iklan ini memiliki hyperlink yang dapat mengarahkan pembaca ke tautan eksternal. Hadirnya iklan yang disisipkan pada Webtoon ini memunculkan program kerja sama antara LINE Webtoon dengan Webtoonist, yaitu Ad Revenue Sharing Program. Ad Revenue Sharing Program merupakan rancangan kerja sama antara LINE Webtoon dengan Webtoonist untuk memberikan aliran pendapatan partisipatif yang berkelanjutan dengan menempatkan iklan pada seri Webtoon yang diunggah.

Sementara bentuk webtoon type juga telah diterapkan di beberapa Webtoon Indonesia, seperti misalnya terlihat di Webtoon dengan judul 'Eggnoid' karya Archie The Red Cat (Agnes, 2017a). Pada salah satu serinya, digambarkan tokoh utama dalam Webtoon tersebut sedang makan di restoran Burger King. Dari hasil kerja sama dengan suatu brand atau merek membantu Webtoonist mendapatkan penghasilan tambahan. 


\section{Webtoonist Menjadi Peluang Pekerjaan}

Hadirnya Webtoon memberikan suatu peluang pekerjaan baru, yaitu menjadi sorang Webtoonist. Webtoonist adalah sebutan bagi individu yang merupakan seorang kartunis yang menerbitkan kartunnya di situs web (Eun-young, 2012). Webtoon memberikan kesempatan bagi siapa saja untuk dapat menerbitkan karyanya melalui program LINE Webtoon Discover. LINE Webtoon Discover atau singkatnya disebut Discover adalah platform tak berbayar dan terbuka bagi para pembuat komik untuk menerbitkan komik digitalnya dan berkesempatan terhubung dengan pembaca di seluruh dunia, serta memonetisasi karyanya melalui hubungan kemitraan dengan Patreon (www.webtoons.com, 2019b). Discover creator memiliki pilihan produk untuk mempromosikan komiknnya dan melakukan interaksi dengan pembaca yang menjadi penggemar karyanya. Setiap komik yang diterbitkan akan mendapatkan kesempatan untuk ditanggapi atau dikomentari oleh pembacanya, dapat dibagikan ke media sosial lainnya, pembaca yang berlangganan akan mendapatkan pemberitahuan apabila terdapat konten baru dari komik, dan pembaca juga dapat memberikan penilaian dari konten komik yang diterbitkan. Discover creator dapat menghubungkan akun Patreon-nya dengan komik yang diterbitkan untuk dapat mendapat dukungan langsung dari penggemarnya. Discover creator akan mendapatkan akses langsung dengan status perlindungan dan laporan statistik pembaca pada akunnya.

Selain Discover, Webtoon juga meluncurkan program Featured Creator. Featured Creator adalah pencarian Webtoonist yang dipilih dari Discover setiap bulannya, dimana judul yang tampil akan mendapatkan beberapa keuntungan, yaitu:

1. Bayaran bulanan

LINE Webtoon menjamin kompensasi yang kompetitif bagi setiap Webtoonist yang menerbitkan komiknya secara eksklusif dengan menerima pembayaran bulanan yang berkelanjutan. LINE Webtoon juga telah memiliki sistem intensif dengan pembayaran ekstra apabila seri dari judul mencapai popularitas.

2. Mendapatkan penggemar seluruh dunia

LINE Webtoon secara resmi hadir dalam berbagai macam bahasa, seprti bahasa Korea, Inggris, Mandarin, Thailand, Jepang, Indonesia, dan lainnya. Jika judul Webtoon berhasil dan memiliki potensi untuk dapat disebarluaskan secara internasional, maka karya tersebut akan diterjemahkan dan dipublikasikan di layanan LINE Webtoon lainnya.

3. Peluang bisnis baru

Karya Webtoonist yang dipilih menjadi Featured Creator akan mendapatkan kesempatan akses menjadi merchandise, permainan, animasi, televisi, dan peluang fitur dalam film.

Untuk mencari Webtoonist berbakat, LINE Webtoon secara berkala melakukan program yang dikenal dengan Webtoon Challenge. Webtoon Challenge adalah salah satu layanan dari LINE Webtoon yang disediakan bagi penggunanya sebagai platform untuk mengunggah karyanya sebagai konten dan mendukung Webtoonist yang populer menjadi seniman komik profesional (www.webtoons.com, 2017). Webtoon Challenge dipilih secara berkala setiap bulannya dan diterapkan di berbagai negara yang menjadi pasar LINE Webtoon, seperti Korea, Indonesia, Jepang, Amerika, Thailand, dan Taiwan. Setiap karya dari Webtoon Challenge dapat dinikmati pengguna LINE Webtoon, tetapi pemilihan pemenang ditentukan oleh tim konten Webtoon (help2.line.me, 2019). Pemenang utama akan mendapatkan hadiah berupa uang dan berkesempatan menjadi Webtoonist resmi. 
Selain Webtoon Challenge, LINE Webtoon juga membuat program yang disebut dengan Webtoon Contest. Webtoon Contest adalah kompetisi berskala nasional yang terbuka untuk umum yang memiliki minat untuk mempublikasikan komik digitalnya (Agnes, 2015a). Pemenang dari kontes ini akan mendapatkan hadiah berupa uang dan kesempatan untuk karyanya dipublikasikan secara regular di LINE Webtoon. Berbeda dengan Webtoon Challenge, pemenang dalam Webtoon Contest terbagi menjadi beberapa kategori, seperti paling kocak, paling epik, paling menyentuh, dan paling ngeri.

Para pemenang dari Webtoon Challenge dan Webtoon Contest disebut dengan artis amatir (amateur artists). Artis amatir (amateur artists) adalah Webtoonist yang tidak memiliki kontrak dengan portal atau agen komik yang bertindak sebagai perantara dan perekrutan artis komik; dapat secara langsung berpartisipasi dalam kontes secara online (Lynn, 2015).

Dalam platform Webtoon termasuk LINE Webtoon melakukan klasifikasi kelompok pada Webtoonist yang mengunggahnya yaitu pemula (rookies), kelas menengah (middle class), and kelas atas (stars) (Lynn, 2015). Kelompok Webtoonist ini dibagi dengan rasio yang berbeda, yaitu $30 \%$ untuk pemula, 50\% untuk kelas menengah, dan 20\% untuk kelas atas. Kelompok kelas ini akan menjadi pembeda tingkat pembayaran per judul atau serinya yang juga diakumulasi dengan peringkat pembaca, track record sebelumnya, jumlah pembaca, dan frekuensi isu.

\section{Tren Adaptasi LINE Webtoon Menjadi Serial TV dan Film}

Dalam bisnis di Korea Selatan, sutu produk dapat mengalami produksi sekunder atau tersier (Lynn, 2015). Produksi ulang ini juga terjadi pada hasil karya Webtoon, dimana dari bentuk komik dapat diadaptasi menjadi bentuk lain seperti film atau drama, yang dikenal dengan sebutan adaptasi lintas media (cross-media adaptation). Adaptasi lintas media (cross-media adaptation) adalah perpanjangan dari prinsip-prinsip adaptasi dimana cerita, karakter, atau motif yang muncul disesuaikan dengan lingkungan baru yang mampu memberikan makna (Murray dan Weedon, 2011). Webtoon pertama yang berhasil diadaptasikan adalah karya milik Kang Full yang berjudul "Apartment" pada tahun 2006, sebanyak 50 judul mengalami produksi ulang menjadi film, musikal, teater, animasi, drama TV, atau drama internet (Lynn, 2015).

Sepanjang pengembanganya, telah terdapat 20 judul dari LINE Webtoon yang diangkat ke layar besar maupun kecil (Hyo-won, 2017). Selain LINE Webtoon yang memiliki cerita yang menarik, drama seri Korea merupakan salah satu daya tarik yang dinantikan banyak penggemar di seluruh dunia. Tidak hanya diburu oleh pembuat film dan televisi di Korea, adaptasi Webtoon juga sudah merambah pasar Cina dan Netflix, yang merupakan media streaming secara digital (Hyo-won, 2017). Untuk merambah pasar Amerika agar dapat membuat Webtoon diadaptasikan menjadi film atau drama disana, NAVER Corporation telah membangun kerjasama dengan Creative Artists Agency (CAA), yang merupakan agensi besar di Hollywood (Spangler, 2016).

Tren adapatasi dari LINE Webtoon menjadi film atau drama kini telah merambah ke Indonesia. Salah satu karya Webtoonist Indonesia yang diangkat ke layar lebar adalah Webtoon dengan judul "Terlalu Tampan" milik Muhammad Ahmes Avisiena Helvin dan Savenia Melinda (Rosalia, 2019). Film adaptasi Webtoon ini ditayangkan di bioskop Indonesia pada 31 Januari 2019 oleh Visinema Pictures.

Webtoon "Terlalu Tampan" sendiri sudah dibaca sembilan juta kali sejak pertama kali dirilis pada Maret 2017 dan diterjemahkan dalam berbagai bahasa (Rosalia, 2019). Selain itu, Webtoon ini sudah dicetak menjadi buku komik dengan 100 episode oleh Bukune. Film 
"Terlalu Tampan" menjadi fenomena baru di Indonesia, dimana menjadi hasil karya Webtoon pertama yang berhasil mengalami adaptasi. Sementara bentuk adaptasi ke dalam film di Indonesia kebanyakan berasal dari novel yang sudah dilakukan sejak 1926 dengan dengan judul “Loetoeng Kasaroeng" (Djaya, 2015).

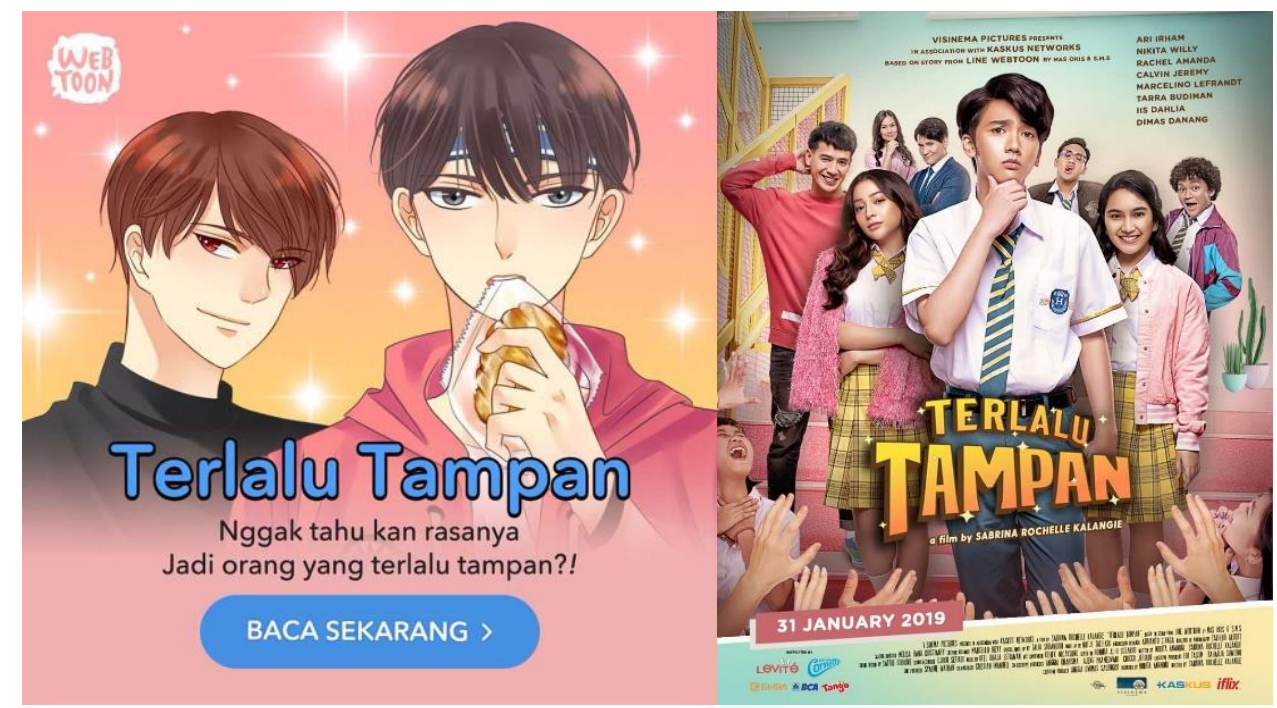

Gambar 4. Perbandingan Poster Webtoon "Terlalu Tampan" Antara LINE Webtoon dengan Versi Adaptasi (Whafsahm, 2019)

\section{KESIMPULAN}

Webtoon merupakan sebutan bagi komik berbasis digital yang telah mengalami perubahan dari komik konvensional yang awalnya disebut manhwa di Korea Selatan. Komik di Korea Selatan merupakan pengaruh dari Jepang, dimana akibat pengunaan ilegal dan krisis ekonomi pada tahun 1997 hingga 1998 membuat industri komik melemah. Bersamaan dengan perkembangan teknologi komunikasi yang pesat di Korea Selatan, berbagai perusahaan teknologi di negara tersebut berusaha mencari cara baru menikmati komik dengan modifikasi digital dan dibentuklah Webtoon.

LINE Webtoon adalah aplikasi komik digital yang dikembangkan oleh NAVER Corporation dan LINE Corporation sejak tahun 2004. LINE Webtoon berusaha merambah pasar global dengan secara resmi dipublikasikan di beberapa negara, seperti Amerika, Jepang, Thailand, Taiwan, dan juga Indonesia. LINE Webtoon telah berhasil menjadi aplikasi komik digital yang populer dengan pada tahun 2017 aplikasi ini telah mencapai 35 juta pengguna aktif di seluruh dunia dan memperoleh pendapatan 7,07 juta dolar AS. Pasar tertinggi LINE Webtoon adalah Indonesia dengan mencapai 6 juta pengguna aktif dan terdapatnya 65 Webtoonist lokal pada tahun 2016.

Berbeda dengan komik konvensional, terdapat elemen-elemen khusus yang dihadirkan pada LINE Webtoon, yaitu cara membacanya secara vertikal dari atas yang dianggap mampu membantu pembaca memahami cerita dengan cepat dan memunculkan perasaan seperti 
menonton film pendek; menghadirkan kolom komentar sebagai tempat bagi pembaca untuk memberikan pendapat melalui pesan teks kepada Webtoonist; dan pengembangan aplikasi yang memungkinkan pembaca menikmati teknologi FX Toon, yang membuat komik yang dibaca dapat memunculkan suara dan gambar bergerak di dalamnya.

Sebagai sebuah industri, LINE Webtoon terus melakukan pengembangan bisnis dalam usahanya, seperti:

1. Menghadirkan konten berbayar yang diterapkan pada LINE Webtoon versi 2.1.2, yang memungkinkan pengguna untuk dapat melakukan pratinjau pada dua episode yang akan ditampilkan selanjutnya.

2. Menghadirkan iklan yang memberikan kesempatan bagi organisasi atau perusahaan melakukan promosi pada produknya dengan menyisipkan iklan (teks, grafik, audio, video, dan atau kombinasinya) atau menjadi bagian dalam cerita yang dihadirkan dalam bentuk gambar pada judul atau seri LINE Webtoon. Selain itu dihadirkan pula program Ad Sharing Revenue yang membagi hasil dari iklan dengan Webtoonist yang bersedia mengiklankan produk tersebut.

3. Pencarian komikus berbakat dengan program Webtoon Challenge dan Webtoon Contest guna menemukan karya-karya Webtoon terbaru yang menarik perhatian pembaca.

Adaptasi lintas media dari karya Webtoon yang memiliki popularitas tinggi, seperti menjadi film, drama, musikal, merchandise, permainan, animasi, dan lainnya.

\section{DAFTAR PUSTAKA}

Acuna, K. (2016). Millions in Korea are obsessed with these revolutionary comics - now they're going global. Diambil 16 Maret 2019, dari https://www.businessinsider.com/what-is-webtoons-2016-2/?IR=T

Afflerbach, P., \& Cho, B.-Y. (2010). Determining and describing reading strategies: Internet and traditional forms of reading. Metacognition, Strategy Use, and Instruction, (May 2016), 201-225. Diambil dari https://www.academia.edu/9456627/Determining and describing reading strateg ies_Internet_and_traditional_forms_of_reading\%0ADetermining and describing reading strategies

AFP. (2015). Korea's new addiction - "Webtoons." Diambil 11 Maret 2018, dari https://www.khaleejtimes.com/lifestyle/art-culture/koreas-new-addiction--webtoons

Aggleton, J. (2018). Defining digital comics: a British Library perspective. Journal of Graphic Novels and Comics, 00(00),1-17. https://doi.org/10.1080/21504857.2018.1503189

Agnes, T. (2015). "Webtoon Contest” Dibuka Hari Ini! Diambil 23 Maret 2019, dari https://hot.detik.com/art/3019446/webtoon-contest-dibuka-hari-ini

Agnes, T. (2016). Pembaca LINE Webtoon Indonesia Terbesar di Dunia. Diambil 11 Maret 2019, dari https://hot.detik.com/art/d-3274551/pembaca-line-webtoon-indonesiaterbesar-di-dunia

Agnes, T. (2017a). Dua Tahun Berdiri, LINE Webtoon Indonesia Diramaikan 65 Komikus Lokal. Diambil 20 Maret 2019, dari https://hot.detik.com/art/d-3502867/dua-tahun- 
berdiri-line-webtoon-indonesia-diramaikan-65-komikus-

lokal?_ga=2.60906863.295744159.1553087817-971489527.1540336106

Agnes, T. (2017b). "Eggnoid" hingga "Wonderwall", Ini Dia 5 LINE Webtoon Indonesia Terfavorit! Diambil 20 Maret 2019, dari https://hot.detik.com/art/d3502935/eggnoid-hingga-wonderwall-ini-dia-5-line-webtoon-indonesiaterfavorit?_ga $=2.161578367 .295744159 .1553087817-971489527.1540336106$

Albert, A., Piera, J., Kyba, C., Brier, J., Claramunt, B., Haklay, M., ... Sturm, U. (2017). Defining principles for mobile apps and platforms development in citizen science. Research Ideas and Outcomes, 3, e21283. https://doi.org/10.3897/rio.3.e21283

Anh, H. N. (2016). Smartphone Industry: the New Era of Competition and Strategy. Centria University of Applied Sciences. Centria University Of Applied Sciences.

Bhaskara, I. L. A. (2019). Webtoon: Hallyu Baru setelah Kpop dan Drama Korea. Diambil 16 Maret 2019, dari https://tirto.id/webtoon-hallyu-baru-setelah-kpop-dan-dramakorea-dfjc

Cohn, N. (2005). Un-Defining "Comics": Separating the cultural from the structural in "comics." International Journal of Comic Art, 7(October), 11.

Djaya, A. B. (2015). Tujuh film adaptasi novel Indonesia laik tonton. Diambil 25 Maret 2019, dari https://beritagar.id/artikel/seni-hiburan/tujuh-film-adaptasi-novel-indonesialaik-tonton-23861

Eun-young, K. (2012). Golden Age of Webtoons, How Are Website Cartoonists? Diambil 22 Maret 2019, dari http://www.theargus.org/gisa_print.asp?no=310

Fatimah, S. (2018). TEACHING WRITING NARRTIVE TEXT BY USING WEBTOON. Journal of English Language Teaching, 7(4).

Fitrianindita, H. (2018). LINE Webtoon Harus Pakai Koin? Diambil 23 Maret 2019, dari https://teknologi.id/ulasan/aplikasi/line-webtoon-harus-pakai-koin/

Gilakjani, P., Sabouri, A., \& Banou, N. (2016). How Can Students Improve Their Reading Comprehension Skill? Journal of Studies in Education, 6(2), 229. https://doi.org/10.5296/jse.v6i2.9201

Hee, E., \& Yeob, S. (2018). Strategy of Expression and Media in Webtoon Advertisement Effect. International Journal of Pure and Applied Mathematics, 118(19), 249-265.

Help2.line.me. (2019). LINE Webtoon. Diambil dari https://help2.line.me/LINE_WEBTOON/pc?lang=id

Hyo-won, L. (2017). Why South Korean Filmmakers Are Adapting Local Webtoons Into Movies and TV Shows. Diambil 24 Maret 2019, dari https://www.hollywoodreporter.com/news/why-south-korean-filmmakers-areadapting-local-webtoons-movies-tv-shows-1054466

Jang, W., \& Song, J. E. (2017). Webtoon as a new Korean wave in the process of glocalization. Kritika Kultura, 2017(29), 168-187. https://doi.org/10.13185/KK2017.02908

Karimova, G. Z. (2014). Defining advertising: A carnivalesque perspective. International Journal of Journalism and Mass Communication, 1(1), 2-10. 
Kilgour, F. G. (1998). The evolution of the book, 189. https://doi.org/10.1017/CB09781107415324.004

Koh, D. Y. (2012). (Un)making the "Korean" Astro Boy atom: National manhwa, Korean pop art, and cultural hybridity. Korea Journal, 52(1), 171-205.

Lee, E., Choi, M., \& Kim, C. (2015). A Study on Kitschy Characteristics and its Consumer s of Webtoon. Journal of Korea Multimedia Society, 18(8), 980-987. https://doi.org/10.9717/kmms.2015.18.8.980

Leiner, B. M. (1997). A brief history of internet. Studies in Health Technology and Informatics, 36, 121-132. https://doi.org/10.3233/978-1-60750-880-9-121

Lestari, S. H. (2018, Agustus). Penetrasi Pengguna Internet Tahun 2018 Diprediksi Tumbuh Hingga 60 Persen. Diambil 9 Maret 2019, dari http://surabaya.tribunnews.com/2018/08/10/penetrasi-pengguna-internet-tahun2018-diprediksi-tumbuh-hingga-60-persen

LICO. (2019). Save Me Episode 6. Diambil 26 Maret 2019, dari https://www.webtoons.com/en/drama/bts-saveme/ep05/viewer?title_no=1514\&episode_no $=6$

Lim, Y. (2012). Seriously, What Are They Reading? An Analysis Of Korean Children's Reading Behavior Regarding Educational Graphic Novels. University of Illinois.

Linecorp.com. (2019). About LINE. Diambil 16 Maret 2019, dari https://linecorp.com/en/company/info

Lynn, H. (2015). Korean Webtoons : Explaining Growth, 16, 1-14.

Macdonald, H. (2016). LINE Webtoon: readership is 50\% female. Diambil 24 Maret 2019, dari https://www.comicsbeat.com/line-webtoon-readership-is-50-female/

Mauliansyah, Fiandy. (2016). The Social and Political Aspects of New Media (Menelusuri Jejak Kesadaran Dan Tindakan Kolektif Massa). Source: Jurnal Ilmu Komunikasi.

Murray, S., \& Weedon, A. (2011). Beyond medium specificity: Adaptations, cross-media practices and branded entertainments. Convergence, 17(1), 3-5. https://doi.org/10.1177/1354856510386861

Navercorp.com. (2019). NAVER. Diambil 16 Maret 2019, dari https://www.navercorp.com/en/naver/company

Norin, T. A. (2018). Media Conversion From Webtoon To Television. Stockholms Universitet.

Quimchee. (2018). I Love Yoo Episode 27. Diambil 26 Maret 2019, dari https://www.webtoons.com/en/romance/i-love-yoo/episode-

27/viewer?title_no=986\&episode_no $=29$

Rina, S. (2016). Online Webtoon Users - Survey Report. Diambil 24 Maret 2019, dari https://blog.jakpat.net/online-webtoon-users-survey-report/

Rosalia, I. (2019). Terlalu Tampan, dari komik daring menjadi film layar lebar. Diambil 25 Maret 2019, dari https://beritagar.id/artikel/seni-hiburan/terlalu-tampan-darikomik-daring-menjadi-film-layar-lebar 
Sidik, F. (2018). Pengguna Perangkat Mobile di Indonesia Semakin Tinggi, Ini Datanya! Diambil Maret 2019, dari https://ekonomi.bisnis.com/read/20180201/101/733037/pengguna-perangkatmobile-di-indonesia-semakin-tinggi-ini-datanya

Spangler, T. (2016). Korea's LINE Webtoon Digital-Comics Publisher Signs With CAA for TV and Film Projects. Diambil 24 Maret 2019, dari https://variety.com/2016/digital/asia/line-webtoon-comics-caa-tv-film$1201847907 /$

Turow, J. (2009). Media Today: An Introduction to Mass Communication (3 ed.). New York: Routledge.

Verma, J., \& Malviya, V. (2010). The Impact of Internet and Digital Media on Reading Habit. In IASLIC 24th National Seminar. Gorakhpur: Deen Dayal Upadhaya Gorakhpur University.

Webtoon.com. (2019). About LINE Webtoon. Diambil 16 Maret 2019, dari https://www.webtoons.com/en/about

Webtoons.com. (2017). Kebijakan Mengunggah WEBTOON CHALLENGE. Diambil 23 Maret 2019, dari https://www.webtoons.com/id/terms\#challengePolicy

Webtoons.com. (2018). AD REVENUE SHARING TERMS. Diambil 23 Maret 2019, dari https://www.webtoons.com/en/terms\#adRevenueSharingPolicy

Webtoons.com. (2019a). LINE WEBTOON Terms of Use. Diambil 24 Maret 2019, dari https://www.webtoons.com/en/terms

Webtoons.com. (2019b). Populer. Diambil 17 Maret 2019, dari https://www.webtoons.com/id/top

Webtoons.com. (2019c). Publishing On Webtoon.

Whafsahm. (2019). Webtoon-Based "Terlalu Tampan" Feature Film to be Released in January 2019. Diambil 26 Maret 2019, dari https://www.kaorinusantara.or.id/english/10256/webtoon-terlalu-tampan-filmrelease-january-2019 